\title{
Acute pericarditis: a presenting manifestation of aortic dissection
}

\author{
Hursit Soyer
}

Department of Cardiology, Nisa Hospital, Istanbul, Turkey

\section{Correspondence to} Dr Hursit Soyer,

hursitsoyer@hotmail.com

Accepted 16 June 2016
CrossMark

To cite: Soyer H. BMJ Case Rep Published online: [please include Day Month Year] doi:10.1136/bcr-2016215853

\section{DESCRIPTION}

A patient presented to the outpatient clinic (nonemergency), with non-exertional retrosternal chest pain of 3 days' duration. The pain was sharp in character and worsened by being in a supine position. The patient had no history of cardiac disease or hypertension and was an active smoker. Phenotypic characteristics of Marfan or Ehlers-Danlos syndrome were absent. On physical examination, the patient had diaphoresis. Vital signs were normal, body temperature was $36.8^{\circ} \mathrm{C}$ and heart rate was $88 \mathrm{bpm}$ with no dysrhythmia. Blood pressure was $120 / 70$ and $110 / 70 \mathrm{~mm} \mathrm{Hg}$ in the right and left arms, respectively. On auscultation, a pericardial friction rub was heard over the left upper sternal border. No cardiac murmurs were noted. Pulses were equal throughout all extremities. Initial ECG (figure 1) showed a normal sinus rhythm. A concave upward ST segment elevation in leads I, II, aVL, aVF and V2-6 was evident

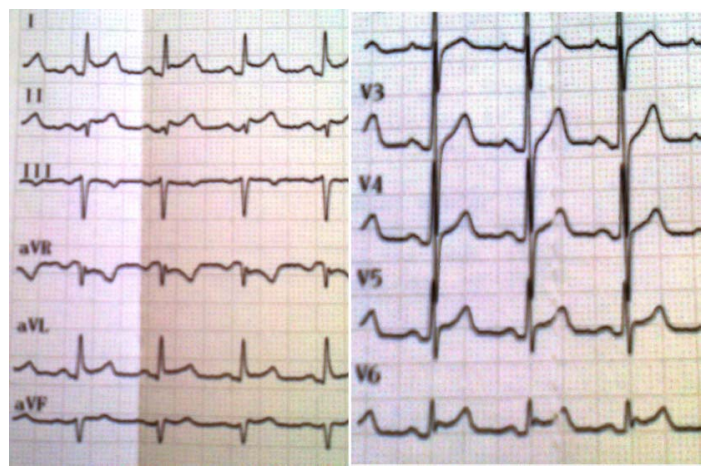

Figure 1 Twelve-lead ECG showing normal sinus rhythm, with concave upward ST segment elevation in leads I, II, aVL, aVF and V2-6, no reciprocal ST segment depression (except in aVR) and PR segment depression in leads I, II, aVL and V3-6. with no reciprocal ST segment depression (except in aVR). In addition, PR segment depression was seen in leads I, II, aVL and V3-6. A bedside transthoracic echocardiogram (TTE) was performed, which revealed normal ventricular function and wall motion. TTE also showed the presence of pericardial effusion $(5 \mathrm{~mm})$ and the ascending aorta was dilated $(4.8 \mathrm{~cm})$. However, neither aortic flap nor aortic valve regurgitation was seen. Troponin-I level was normal $(<0.01 \mu \mathrm{g} / \mathrm{L})$. However, C reactive protein $(218 \mathrm{mg} / \mathrm{L}$, reference range $<10 \mathrm{mg} / \mathrm{L})$ and white cell count were high $\left(10.510^{3} / \mu \mathrm{L}\right)$. After this initial clinical and laboratory work up, aortic dissection was suspected on the basis of the following signs and symptoms: continuing sweating, absence of high fever, severe chest pain disproportionate to the severity of clinically detected acute pericarditis and presence of aortic aneurysm as detected on bedside TTE. D-dimer test and CT angiography were performed. D-dimer was $>10.000 \mathrm{ng} / \mathrm{mL}$ (reference range, $<500 \mathrm{ng} / \mathrm{mL}$ ). CT angiography of the thorax and abdomen showed the presence of a type I DeBakey aortic dissection, intramural thrombus in the ascending aorta and pericardial effusion (figure 2). The dissection involved the ascending aorta (figure $2 \mathrm{~B}$ ), aortic arch and the descending aorta (figure 2A). In addition, the ascending aorta was dilated. An increase in the volume of pericardial effusion was also noted as compared to the initial TTE findings (figure 2B). Emergency surgery was carried out. During the operation, dissection was found to be starting at the supracoronary level but sparing the aortic valve, with intramural haematoma in the aorta and thrombus in the false lumen. In addition, there was abundant haemorrhagic effusion in the pericardial space. The patient had postoperative mediastinal bleeding and died from irreversible shock 24 hours later.

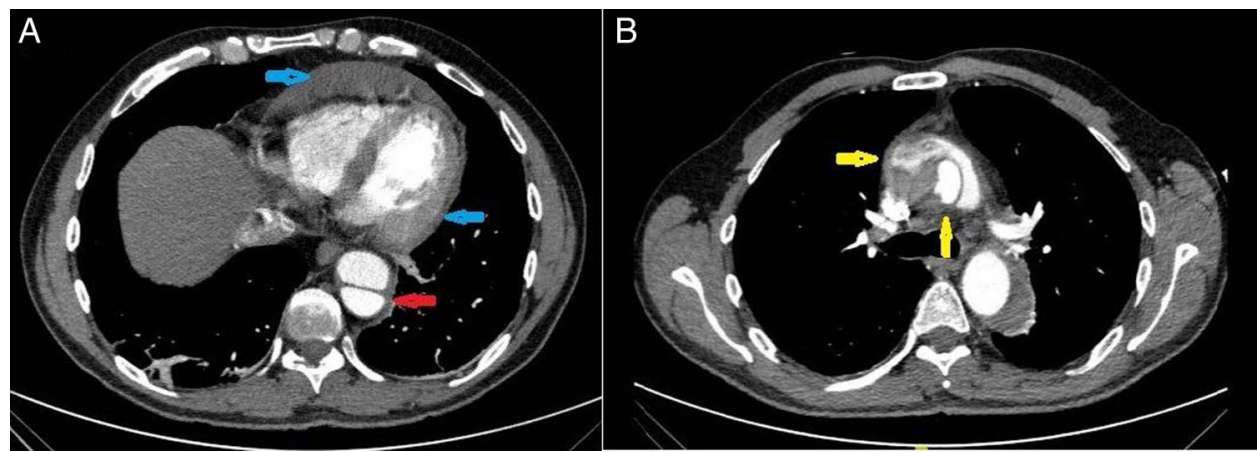

Figure 2 Contrast-enhanced CT image of the thorax at the level of the descending aorta showing a prominent dissection plane (red arrow) and abundant pericardial effusion (blue arrows) (A). Thoracic view at the level of the ascending aorta showing a prominent dissection plane and thrombus, and dilation of ascending aorta (yellow arrows) (B). 


\section{Learning points}

- Aortic dissection can cause a wide variety of presentations, depending on the aortic segment involved.

- Aortic dissection is most commonly misdiagnosed as myocardial infarction or other causes of chest pain such as pulmonary embolisation.

- Acute pericarditis may be the predominant feature in aortic dissection.

Development of pericarditis is not an unexpected condition in cases with proximal aortic dissection. ${ }^{1}{ }^{2}$ However, as in our case, pericarditis with its full clinical characteristics may be the presenting feature of aortic dissection. Our case shows that acute pericarditis, particularly its characteristic pericardial chest pain, may dominate the clinical picture by mimicking characteristic chest pain of acute dissection.

Competing interests None declared.

Provenance and peer review Not commissioned; externally peer reviewed.

\section{REFERENCES}

1 Greenberg DI, Davia JE, Fenoglio J, et al. Dissecting aortic aneurysm manifesting as acute pericarditis. Arch Intern Med 1979;139:108-9.

2 Bains SR, Kedia A, Roldan CA. Pericarditis as initial manifestation of proximal aortic dissection in young patients. Am J Emerg Med 2008:26:379.e3-5.

Copyright 2016 BMJ Publishing Group. All rights reserved. For permission to reuse any of this content visit

http://group.bmj.com/group/rights-licensing/permissions.

BMJ Case Report Fellows may re-use this article for personal use and teaching without any further permission.

Become a Fellow of BMJ Case Reports today and you can:

- Submit as many cases as you like

- Enjoy fast sympathetic peer review and rapid publication of accepted articles

- Access all the published articles

- Re-use any of the published material for personal use and teaching without further permission

For information on Institutional Fellowships contact consortiasales@bmjgroup.com

Visit casereports.bmj.com for more articles like this and to become a Fellow 